\title{
Isolation and characterization of novel Helicobacter spp. from the gastric mucosa of harp seals Phoca groenlandica
}

\author{
Claudia G. Harper ${ }^{1}$, Shilu Xu ${ }^{1}$, Arlin B. Rogers ${ }^{1}$, Yan Feng ${ }^{1}$, Zeli Shen ${ }^{1}$, \\ Nancy S. Taylor ${ }^{1}$, Floyd E. Dewhirst ${ }^{2,3}$, Bruce J. Paster ${ }^{2,3}$, Melissa Miller ${ }^{4}$, \\ Jenifer Hurley ${ }^{5}$, James G. Fox ${ }^{1, *}$ \\ ${ }^{1}$ Division of Comparative Medicine, Massachusetts Institute of Technology, 77 Massachusetts Avenue, Building 16, \\ Room 825C, Cambridge, Massachusetts 02139, USA \\ ${ }^{2}$ Department of Molecular Genetics, Forsyth Institute, Boston, Massachusetts 02115, USA \\ ${ }^{3}$ Department of Oral and Developmental Biology, Harvard School of Dental Medicine, Boston, Massachusetts 02115, USA \\ ${ }^{4}$ Department of Fish and Game and University of California Davis, Marine Wildlife Veterinary Care and Research Center, \\ Santa Cruz, California 95060, USA \\ ${ }^{5}$ California State University, Moss Landing Marine Laboratory, Moss Landing, California 95039, USA
}

\begin{abstract}
Since the recent discovery of Helicobacter cetorum in cetaceans and its role in the development of gastritis, speculation has existed as to whether pinnipeds have Helicobacter spp. associated gastritis and peptic ulcer disease. The gastric mucosa of 4 stranded harp seals Phoca groenlandica from the Massachusetts coastline were assessed for Helicobacter spp. by culture and PCR. We cultured 2 novel Helicobacter spp. from the pyloric antrum of 1 of the 4 harp seals studied, and identified these by PCR in 2 of the 4 seals. Both gram-negative bacterial isolates were catalaseand oxidase-positive. However, a fusiform helicobacter with flexispira morphology was ureasepositive, and a spiral-shaped helicobacter was urease-negative. Slender, spiral and fusiform-shaped bacteria were detected in the gastric mucosa by the Warthin-Starry stain. Histopathologic analysis revealed mild diffuse lymphoplasmacytic gastritis within the superficial mucosa of the pyloric antrum of both infected seals. The 2 bacterial isolates were classified by 16S rRNA analysis; they clustered with other enteric helicobacters and represent 2 novel Helicobacter spp. The urease-negative bacterial isolate clustered with $H$. canis and the urease-positive isolate clustered with an isolate from a sea lion and isolates from sea otters. This cluster of pinniped isolates has $97 \%$ similarity to a number of Helicobacter species, but appears to be most closely related to other helicobacters with flexispira morphology. These findings suggest that the novel Helicobacter spp. may play a role in the etiopathogenesis of gastrointestinal diseases in pinnipeds. To our knowledge, this represents the first isolation and characterization of a novel Helicobacter spp. from pinnipeds.
\end{abstract}

KEY WORDS: Harp seal · Pinniped · Helicobacter infection · Gastritis · Cryptosporidium

\section{INTRODUCTION}

There are at least 24 formally named Helicobacter spp., the majority of which are proven or suspected gastrointestinal pathogens and have zoonotic potential (Fox 1997, 2002). In humans, H. pylori is an important pathogen that can lead to chronic gastritis, gastric ulcers and gastric cancer (Versalovic \& Fox 2001, 2003). Helicobacter spp. have been isolated from the gastrointestinal tract of a wide variety of mammals such as dogs, cats, ferrets, pigs, monkeys, dolphins and cheetahs, to name a few. In some cases, gastric helicobacters have been associated with gastritis with and without ulcers in their hosts, whereas in other cases the 
association seems to be unclear (Fox 2002, Harper et al. 2002a, Doster 2000). Recently, H. cetorum was isolated from cetaceans and thought to be involved in the development of gastritis (Harper et al. 2000, 2002a,b).

Like dogs, seals are monogastric, and gastric ulcers are usually associated with parasites and foreign bodies, although in some cases the cause of ulcers is unknown (Sweeney 1974, 1990, Bishop 1979, McClelland 1980). The distribution of harp seals ranges from the White Sea at Jan Mayen, Newfoundland, to the Gulf of St. Lawrence (Riedman 1990).

The goal of this study was to determine if Helicobacter spp. could be isolated from the gastric mucosa of stranded pinnipeds.

\section{MATERIALS AND METHODS}

Seals. We evaluated 4 wild, stranded harp seals. All had died along the shores of New England, USA. Strandings occurred in Massachusetts in the winter of 2001, and the carcasses were collected by the New England Aquarium Marine Mammal Stranding.

Sample collection. The stomach body and pyloric antrum were obtained by the submittors from 4 harp seals for culture, PCR and histopathology. Each sample measured $2 \mathrm{~cm} \times 2 \mathrm{~cm}$. A Massachusetts Institute of Technology (MIT) accession number was assigned to each seal: Seal 1 = MIT 01-5353, Seal 2 = MIT 01-5354, Seal 3 = MIT 01-5355 and Seal $4=$ MIT 01-5529. These MIT accession numbers will be used throughout this paper.

Microaerobic culture and biochemical characterization. The gastric tissue samples were rinsed with sterile physiological saline and placed in a vial with $3 \mathrm{ml}$ of $20 \%$ glycerol in brucella broth (Remel Labs, Lenexa, Kansas). The vials were maintained at $-70^{\circ} \mathrm{C}$ prior to culture. Culture media were Trypticase soy agar with 5\% sheep blood and TVP (trimethoprim, vancomycin, and polymyxin) and CVA (cefoperazone, vancomycin, and amphotericin B) antibiotic-impregnated media (Remel). In addition, selective antibiotic medium (ABM) contained the following components: blood agar base (Remel), 5\% horse blood (Remel),
$50 \mu \mathrm{g} \mathrm{ml} \mathrm{m}^{-1}$ of amphotericin B, $100 \mu \mathrm{g} \mathrm{ml}^{-1}$ of vancomycin, $3.3 \mu \mathrm{g} \mathrm{ml}^{-1}$ of polymyxin $\mathrm{B}, 200 \mu \mathrm{g} \mathrm{ml}^{-1}$ of bacitracin, and $10.7 \mu \mathrm{g} \mathrm{ml}{ }^{-1}$ of nalidixic acid (Sigma Chemical Co., St. Louis, Missouri). A small amount of stomach tissue was homogenized in $1 \mathrm{ml}$ of brucella broth (Difco Laboratories, Detroit, Michigan) containing $5 \%$ fetal calf serum (Summit Technologies, Fort Collins, Colorado) in a glass tissue-grinder. Approximately $100 \mu \mathrm{l}$ of sample was applied directly to TVP, CVA, and ABM media. Half of the remaining sample was filtered through a $0.45 \mu \mathrm{m}$ pore-size filter onto a blood agar plate. The plates were incubated at $37^{\circ} \mathrm{C}$ under microaerobic conditions for 2 to $4 \mathrm{wk}$ in vented jars containing $\mathrm{N}_{2}: \mathrm{H}_{2}: \mathrm{CO}_{2}$ (80:10:10). Biochemical and morphological analyses following a previously described protocol were performed on isolated bacteria (Mendes et al. 1996).

DNA extraction and PCR analysis. DNA was extracted from the cultured bacterial isolates and from the gastric tissues with a 'high pure PCR template preparation kit' (Roche Molecular Biochemicals, Indianapolis, Indiana). Helicobacter species-specific primer pairs C97 and C05 were used to generate 16S rRNA amplicons of 1200 bases (Table 1) (Fox et al. 1998, Harper et al. 2002a). We used $10 \mu \mathrm{l}$ of the DNA preparation for PCR. PCR amplification conditions were as previously described by Fox et al. (1998).

Restriction fragment length polymorphism analysis. DNA fragments of $1.2 \mathrm{~kb}$ from the cultured bacterial isolates were subjected to restriction fragment length polymorphism (RFLP) analysis using restriction endonucleases AluI and HhaI (New England Biolabs, Beverly, Massachusetts). Each reaction contained $10 \mathrm{U}$ of either AluI or HhaI, $2 \mu$ l of restriction buffer (New England Biolabs) and $16 \mu \mathrm{l}$ of PCR product. Reactions were incubation at $37^{\circ} \mathrm{C}$ for $2 \mathrm{~h}$. The products were examined by electrophoresis through a $6 \%$ Visigel separation matrix (Stratagene, La Jolla, California), stained with ethidium bromide and viewed under UV illumination.

Amplification of $16 \mathrm{~S}$ cistrons by $\mathrm{PCR}$ and purification of PCR products from cultured bacteria. The rRNA cistrons from the gastric mucosa culture isolates (MIT 01-5529-A and MIT 01-5529-B) were amplified with universal bacterial primers F24 and F25 for 16S

Table 1. PCR primers used. Primers F24 and F25 were used for PCR of genomic DNA for cycle sequencing. Primers C97 and C05 were used to amplify a $1.2 \mathrm{~kb}$ product from bacterial cultures

\begin{tabular}{|lllll|}
\hline Primer & Position & Orientation & PCR-specificity & Sequence \\
\hline F24 & $9-27$ & Forward & Universal & GAGTTTGATYMTGGCTCAG \\
F25 & $1525-1541$ & Reverse & Universal & AAGGAGGTGWTCCARCC \\
C97 & $276-291$ & Forward & Helicobacter & GCTATGACGGGTATCC \\
C05 & $1477-1495$ & Reverse & Helicobacter & ACTTCACCCCAGTCGCTG \\
\hline
\end{tabular}


rRNA (Table 1) (Fox et al. 1998). Hot-start PCR was performed in thin-walled tubes with a Perkin-Elmer 9700 thermocycler and $1 \mu \mathrm{l}$ of the DNA template was added to a reaction mixture ( $50 \mu \mathrm{l}$ final volume) containing 20 pmol of each primer, $40 \mathrm{nmol}$ of deoxynucleoside triphosphates, and $1 \mathrm{U}$ of Taq 2000 polymerase (Stratagene) in buffer containing Taqstart antibody (Sigma, St. Louis). In a hot-start protocol, samples were preheated at $95^{\circ} \mathrm{C}$ for 8 min followed by amplification under the following conditions: denaturation at $95^{\circ} \mathrm{C}$ for $45 \mathrm{~s}$, annealing at $60^{\circ} \mathrm{C} 45 \mathrm{~s}$, and elongation for $1.5 \mathrm{~min}$ with an additional $5 \mathrm{~s}$ for each cycle. A total of 30 cycles were performed, followed by a final elongation step at $72^{\circ} \mathrm{C}$ for $10 \mathrm{~min}$. The PCR amplicons were examined by electrophoresis in $1 \%$ agarose gel. DNA was stained with ethidium bromide and visualized under short-wavelength UV light. PCR products were purified with QIA quick PCR purification kit (Qiagen, Valencia, California).

16S rRNA gene sequencing and data analysis. Purified DNA from PCR was sequenced with an ABI prism cycle-sequencing kit (BigDye Terminator Cycle Sequencing kit with AmpliTaq DNA polymerase FS; Perkin-Elmer). The primers used for sequencing were as previously described by Fox et al. (1998). Quarterdye chemistry was used with $80 \mu \mathrm{M}$ primers and $1.5 \mu \mathrm{l}$ of PCR product in a final volume of $20 \mu \mathrm{l}$. Cycle sequencing was performed with an ABI GeneAmp PCR System 9700 with 25 cycles of denaturation at $96^{\circ} \mathrm{C}$ for $10 \mathrm{~s}$ and annealing and extension at $60^{\circ} \mathrm{C}$ for 4 min. Sequencing reactions were run on an ABI 3100 DNA sequencer. Sequence data were entered into RNA, a program set for data entry, editing, sequence alignment, secondary structure comparison, similarity matrix generation, and dendrogram construction for 16S rRNA (Dewhirst et al. 1999). Our database contains over 1000 sequences obtained in our laboratory and over 500 retrieved from GenBank for 16S rRNA. Dendrograms were constructed by the neighbor-joining method (Saitou \& Nei 1987).

Histopathology. Specimens received in vials containing neutral-buffered $10 \%$ formalin were processed by standard histologic methods and embedded in paraffin, and $5 \mu \mathrm{m}$ sections were stained with hematoxylin and eosin or Warthin-Starry silver stain and evaluated by a comparative pathologist.

Electron microscopy. Strains MIT 015529-A and B were examined by electron microscopy. Cells grown on blood agar plates were centrifuged and suspended in $10 \mu \mathrm{M}$ Tris-HCl buffer $(\mathrm{pH}$ 7.4) at a concentration of about $10^{8}$ cells $\mathrm{ml}^{-1}$. One percent (wt/vol) phosphotungstic acid $(\mathrm{pH}$ 6.5) was used to negatively stain the samples. The specimens were examined with a JEOL model JEM1200EX transmission electron microscope operating at $100 \mathrm{kV}$.

\section{RESULTS}

\section{Seals}

After an estimated interval of 12 to $24 \mathrm{~h}$ postmortem, 4 wild stranded harp seals were necropsied and gastric samples were submitted as described in the 'Materials and methods'. Biologists performing the necropsies reported no significant gross lesions.

\section{Microaerobic culture and biochemical characterization of novel Helicobacter spp.}

Two distinct Helicobacter spp. were cultured from the pyloric antrum of 1 stranded harp seal (MIT 015529) (Table 2). The 2 bacterial isolates were differentiated by the letters A and B (MIT 01-5529-A and MIT 01-5529-B). After incubation for 2 to 4 wk under microaerobic conditions, cultures on solid media were visible as a thin, spreading film. The 2 isolates grew under microaerophilic conditions at 37 and $42^{\circ} \mathrm{C}$, but not at $25^{\circ} \mathrm{C}$. Once pure cultures had been established, subsequent passages yielded growth on blood agar plates by 2 to $5 \mathrm{~d}$ at $37^{\circ} \mathrm{C}$. Light microscopy revealed the morphology of MIT 015529-A as fusiform flexispira-type and MIT 01-5529$\mathrm{B}$ as simple spiral. Both were gram-negative. Table 3 lists the biochemical features of the 2 isolates of the Helicobacter spp. from the harp seal compared to

Table 2. Phoca groenlandica. Helicobacter spp. infection of 4 harp seals, detected in gastric samples by culture and PCR. Seals were all stranded on Massachusetts coastline. MIT (Massachusetts Institute of Technology, Cambridge) accession no. and GenBank no. are also shown. +: positive; -: negative

\begin{tabular}{|llccc}
\hline $\begin{array}{l}\text { MIT acces- } \\
\text { sion no. }\end{array}$ & $\begin{array}{l}\text { Gastric } \\
\text { sample }\end{array}$ & GenBank no. & Culture & PCR \\
\hline $01-5529-\mathrm{A}$ & Pyloric antrum & AF AY203898 & $+^{\mathrm{a}}$ & + \\
$01-5529-\mathrm{B}$ & Pyloric antrum & AF AY203899 & $+^{\mathrm{a}}$ & + \\
& Body & - & + \\
$01-5353$ & Pyloric antrum & - & + \\
& Body & - & + \\
$01-5354$ & Pyloric antrum & - & - \\
& Body & - & - \\
$01-5355$ & Pyloric antrum & - & - \\
& Body & - & - \\
aTwo bacterial isolates cultured from same individual & & \\
\hline
\end{tabular}


Table 3. Helicobacter spp. Biochemical characteristics of strains isolated from harp seal Phoca groenlandica compared to those of other Helicobacter species. +: positive; -: negative. AWD: Atlantic white-sided dolphin; GGT: gamma glutamyl transpeptidase activity; nd: not determined; S: sensitive; R: resistant; I: intermediate

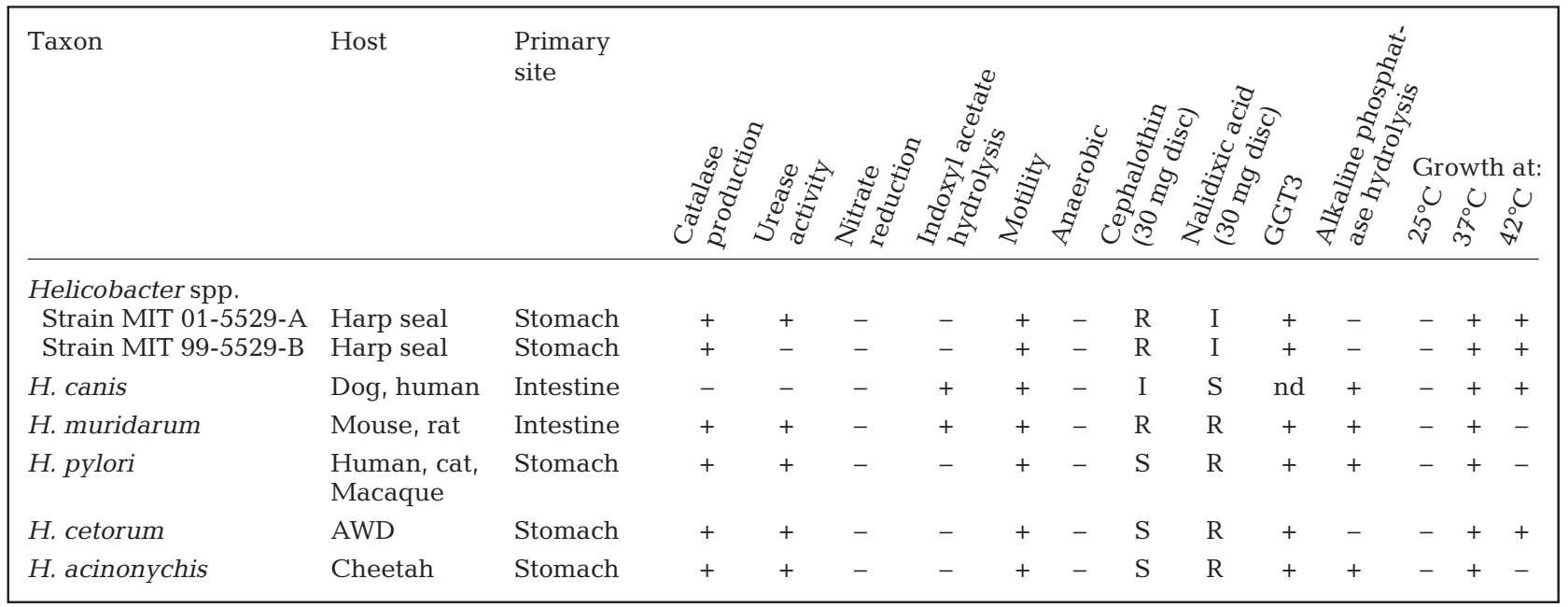

other gastric and enteric Helicobacter spp. Strain MIT 01-5529-A was oxidase-, catalase-, and urease-positive. The strain was negative for nitrate reduction, alkaline phosphatase hydrolysis, and indoxyl acetate hydrolysis. The strain was resistant to cephalothin and had intermediate sensitivity to nalidixic acid (Table 3). The biochemical characteristics of Isolate MIT 01-5529-B were identical to those of MIT 015529-A, except that MIT 01-5529-B were ureasenegative.

\section{PCR analysis of gastric tissue}

DNA from the body and pyloric antrum of 4 stranded harp seals was amplified with a Helicobacter speciesspecific primer set (Table 1). Of the 8 tissue specimens analyzed by PCR, 4 from the body and pyloric antrum of the 2 seals (MIT 01-5529 and MIT 01-5353) were positive for the presence of Helicobacter spp. (Table 2, Fig. 1).

\section{PCR analysis of novel Helicobacter spp. isolates and RFLP}

The 2 culture isolates yielded a $1200 \mathrm{bp}$ PCR product using Helicobacter spp.-specific primers (Table 2). We observed 2 different patterns for the 16S rRNA gene PCR products subjected to RFLP analysis with HhaI digestion and 1 pattern when the PCR product was subjected to AluI digestion. This suggests that the 2 helicobacter bacterial isolates differ. Fragment sizes were as predicted by $16 \mathrm{~S}$ rRNA sequence data (Fig. 2).

\section{Sequencing and phylogenetic analysis of novel Helicobacter spp.}

Full 16S rRNA gene sequences were obtained from the 2 bacterial isolates cultured from the harp seal MIT 01-5529. A dendrogram illustrating the relationship of these strains to selected Helicobacter species is shown in Fig. 3. The 16S rRNA sequence of Strain MIT 015529-B was most similar to $H$. canis (98\% similar). The 16S rRNA sequence of strain MIT 01-5529-A formed a

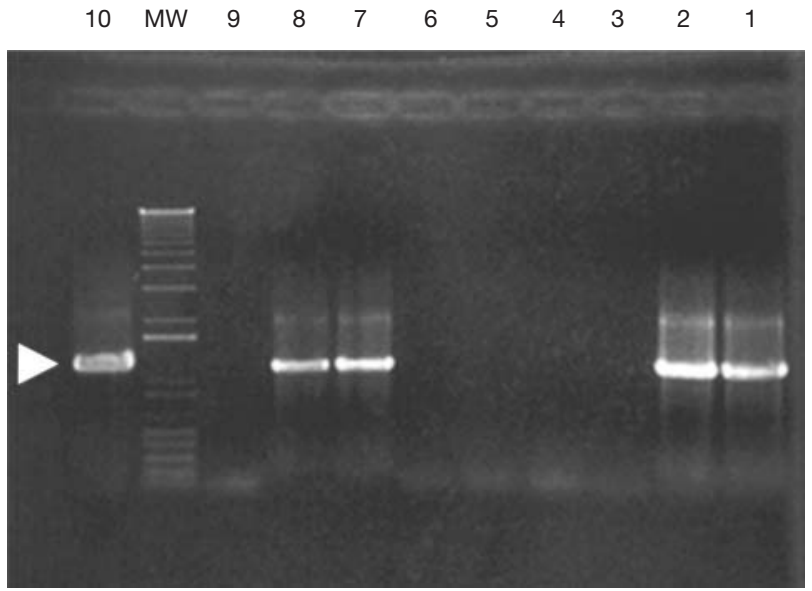

Fig. 1. Phoca groenlandica. Gel electrophoresis with ethidium bromide staining demonstrating $1200 \mathrm{bp}$ PCR product using Helicobacter species-specific primers (arrowhead). Lanes 1 and 2 (MIT 01-5353; Seal 1): harp seal stomach body and DNA from pyloric antrum; Lanes 3 and 4 (MIT 01-5354; Seal 2): stomach body and pyloric antrum; Lanes 5 and 6 (MIT 015355; Seal 3): stomach body and pyloric antrum; Lanes 7 and 8 (MIT 01-5529; Seal 4): stomach body and DNA from pyloric antrum; Lane 9: reagent control; Lane 10: helicobacterpositive control (H. hepaticus). MW: molecular weight 


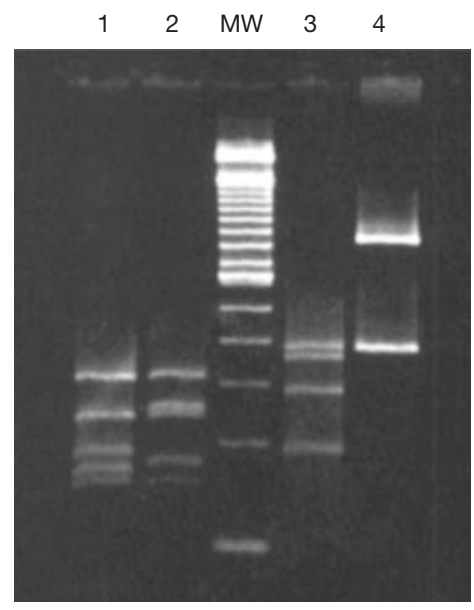

Fig. 2. Helicobacter spp. PCR-RFLP patterns of 1200 base-pair species-specific helicobacter PCR product from harp seal Phoca groenlandica pyloric antrum (MIT 01-5529-A, MIT 01-5529-B). Lane 1: MIT 01-5529-A PCR product from isolate digested by AluI; Lane 2: MIT 01-5529-B PCR product from isolate digested by AluI; Lane 3: MIT 01-5529-A PCR product from pyloric isolate digested by HhaI; Lane 4: MIT 01-5529-B PCR product from pyloric antrum isolate digested by Hha I monophyletic cluster with sequences from a sea lion isolate (MIT 02-5519-C) and sea otter isolates (MIT 016242, MIT 01-5923 and MIT 01-5924). (Descriptions of the sea lion and sea otter isolates will be presented elsewhere.) The pinniped sequences displayed $97 \%$ similarity to a number of Helicobacter spp. including $H$. hepaticus, H. muridarum, H. canis, and Helicobacter sp. Flexispira Taxon 8.

\section{Histopathology}

Due to a prolonged post-mortem interval prior to necropsy, gastric tissue from Seal 01-5353 exhibited mild autolysis of the body and severe autolysis of the antrum which hindered histopathologic analysis; however, no significant infiltrates of leukocytes were identified in the specimen. The gastric antrums from Seals 01-5354 and 5355 were not included in the specimens submitted for analysis. There were scattered small aggregates of mononuclear leukocytes in the deep lamina propria of Seal 01-5354 which were not con-

(\% Difference)

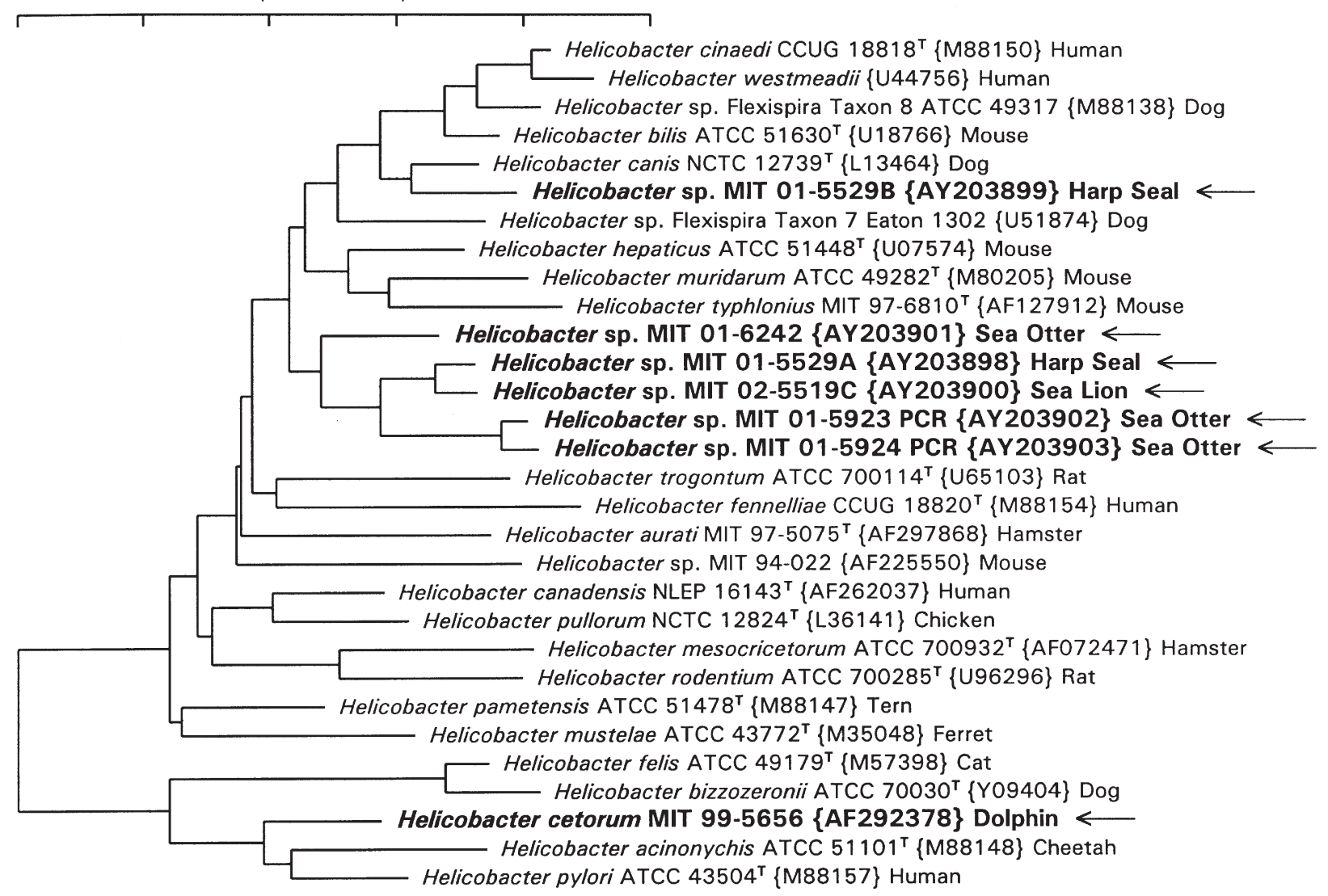

Fig. 3. Helicobacter spp. Dendrogram depicting phylogenetic location based on $16 \mathrm{~S}$ rRNA sequence similarity values. Arrows: sequences from the harp seal Phoca groenlandica (MIT 01-5529-A and MIT 01-5529-B), sea otters, sea lion and dolphin. Numbers in brackets after MIT accession nos. are GenBank accession nos. Scale bar $=2 \%$ difference in nucleotide sequences, determined by measuring length of the horizontal line connecting 2 species 
sidered significant. The only lesion in the stomach of Seal 01-5355 was associated with the presence of several intramuscular helminth parasites that were surrounded by a rim of polymorphonuclear and mononuclear inflammatory cells, including giant cells, with degeneration and necrosis of adjacent smooth muscle fibers.

In contrast to the preceding cases, significant lesions attributable to infectious gastritis were identified in the antrum of Seal 01-5529. There were multifocal surface epithelial erosions lined by mats of fibrin and necrotic cellular debris. The lamina propria exhibited chronic active gastritis characterized by infiltration of neutrophils, lymphocytes, and plasma cells, with fewer macrophages and occasional mast cells and eosinophils. There was multifocal reactive and follicular hyperplasia of gut-associated lymphoid tissue with germinal centers containing plump antigen-presenting cells, and extension of lymphocytes to the epithelial surface (Fig. 4). Antral glands were frequently lined by numerous luminal surface-associated basophilic 3 to $5 \mu \mathrm{m}$ diameter, round organisms with indistinct internal structure, consistent with Cryptosporidium spp. (Fig. 5). Within the lumens of antral and distal oxyntic glands there were variably-sized rafts of viable and degenerate cells and abundant, faintly staining 0.5 to $5 \mu \mathrm{m}$ fusiform and spiral bacteria. These bacteria were strongly argyrophilic, as demonstrated by WarthinStarry stain (Fig. 6). Other antral lesions included surface epithelial degeneration and mucosal vascular congestion. There was mucous neck-cell expansion in the mid-glandular region of the gastric corpus, as demonstrated by Alcian blue-PAS staining, and mild loss of parietal and chief cells. In contrast to the corpus,

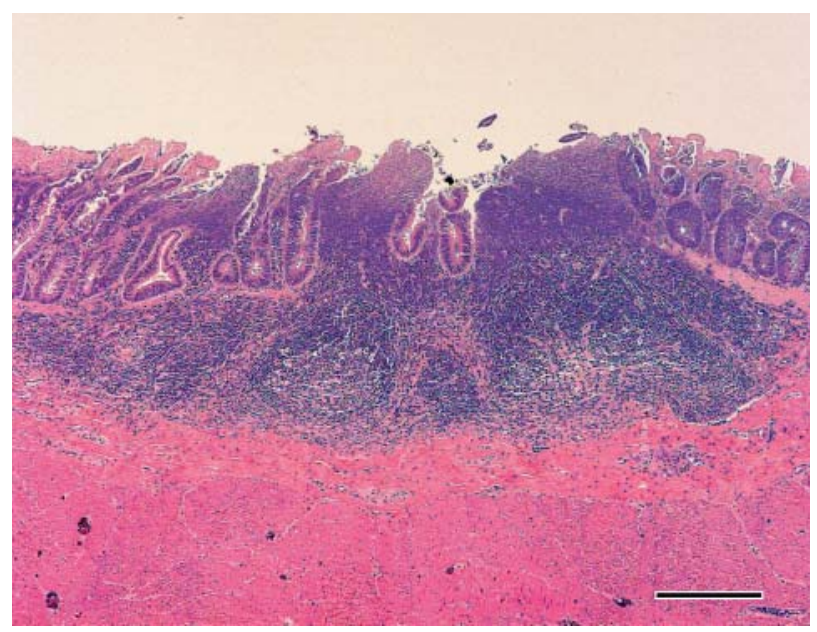

Fig. 4. Phoca groenlandica. Photomicrograph of pyloric antrum of harp seal MIT 01-5529. Mononuclear cell (primarily lymphocytic) infiltrates submucosa and lamina propria extends to subepithelial surface. Note germinal center formation. H\&E. Scale bar $=300 \mu \mathrm{m}$

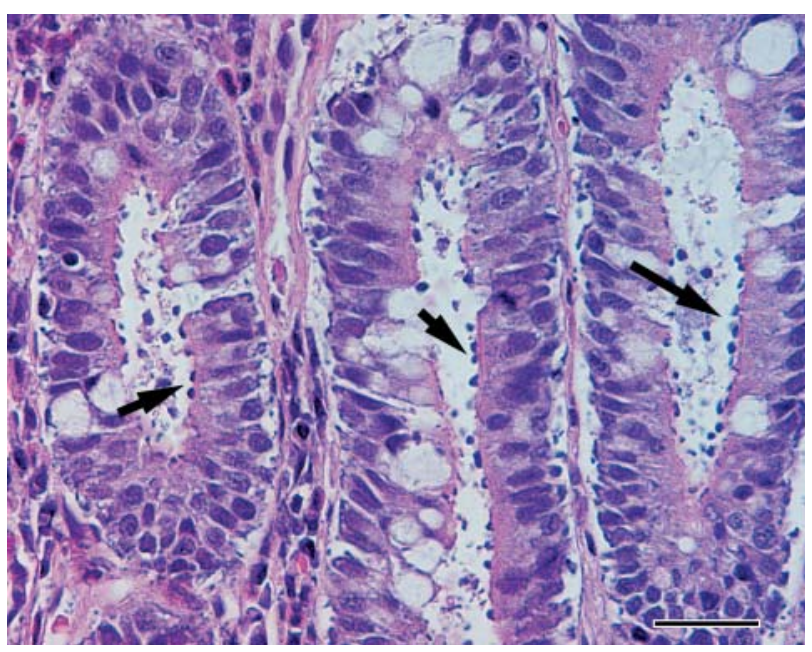

Fig. 5. Phoca groenlandica. Photomicrograph of pyloric antrum of harp seal MIT 01-5529. Numerous surface-associated 3 to $5 \mu \mathrm{m}$, round, basophilic organisms, consistent with Cryptosporidium spp., line mucus-gland epithelial cells. H\&E. Scale bar $=30 \mu \mathrm{m}$

there was a near total loss of mucin production by the antral glands.

\section{Electron microscopy}

The bacterial isolate MIT 01-5529-A measured $0.5 \times$ $5.5 \mu \mathrm{m}$ and had typical flexispira morphology with periplasmic fibers and 7 to 8 sheathed flagella at each end (Figs. 7 \& 8). Isolate MIT-01-5529-B was a small spiral organism, measuring $0.2 \times 1 \mu \mathrm{m}$, with single sheathed flagella at one end (Fig. 9).

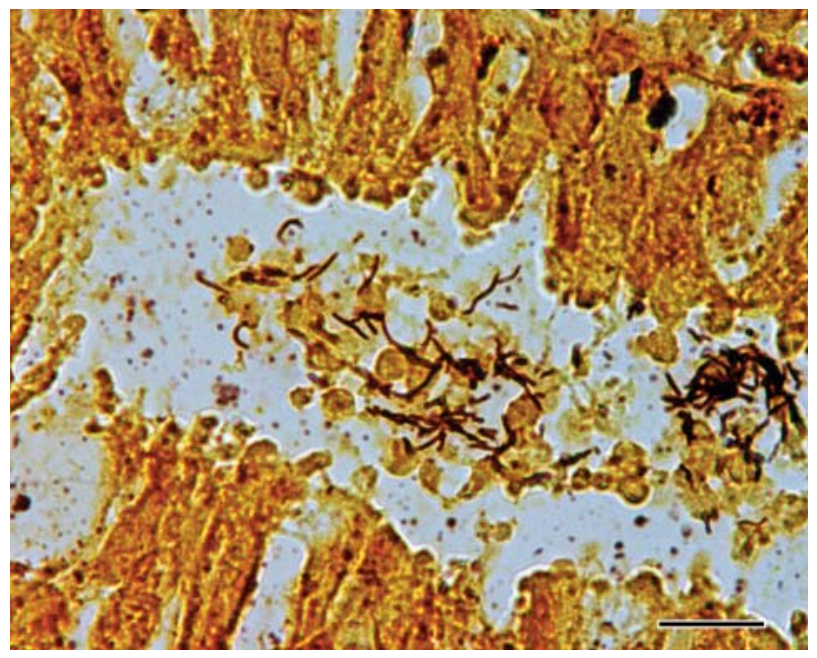

Fig. 6. Phoca groenlandica. Photomicrograph of pyloric antrum of harp seal MIT 01-5529 showing numerous $\sim 1 \times 4$ to $6 \mu \mathrm{m}$ curved and spiral argyrophilic bacteria in surface mucus layer. Warthin-Starry stain. Scale bar $=12 \mu \mathrm{m}$ 
Fig. 7. Helicobacter sp. Transmission electron micrograph of novel urease-positive bacterial isolate (MIT 01-5529A), illustrating fusiform morphology with periplasmic fibers and multiple bipolar sheathed flagella. Scale bar = $0.5 \mu \mathrm{m}$

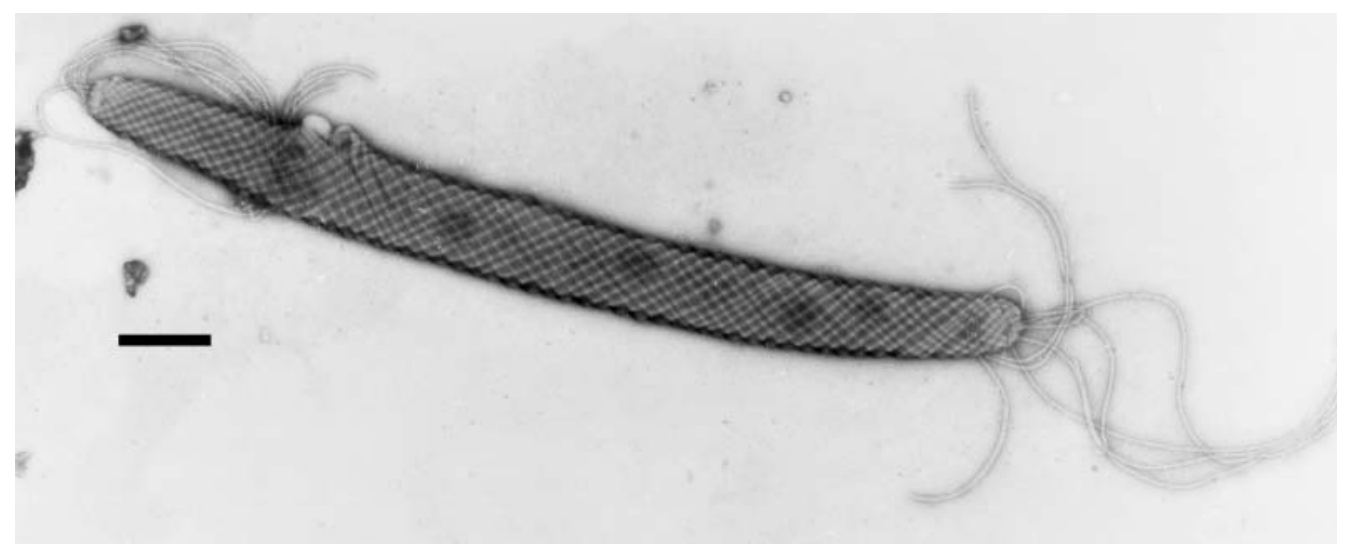

\section{Nucleotide sequence accession numbers}

The 16S rRNA gene sequences from the seal Helicobacter spp. MIT 01-5529-A and MIT 01-5529-B were deposited in GenBank under accession number AF203898 and AF203899 respectively. The GenBank accession numbers for other pinniped and reference strains are given in Fig. 3.

\section{DISCUSSION}

In this study we isolated and described 2 novel Helicobacter spp. from the pyloric antrum of 1 stranded harp seal (MIT 01-5529). Furthermore, we identified gastric helicobacters in the body and pyloric antrum of 2 of the 4 harp seals (MIT 01-5353 and MIT 01-5529) by PCR using Helicobacter species-specific primers.

One of the Helicobacter spp. isolated from the harp seal stomach was urease-, catalase- and oxidase-positive, which is biochemically consistent with other gastric helicobacters (MIT 01-5529-A). Ultrastructurally, this strain

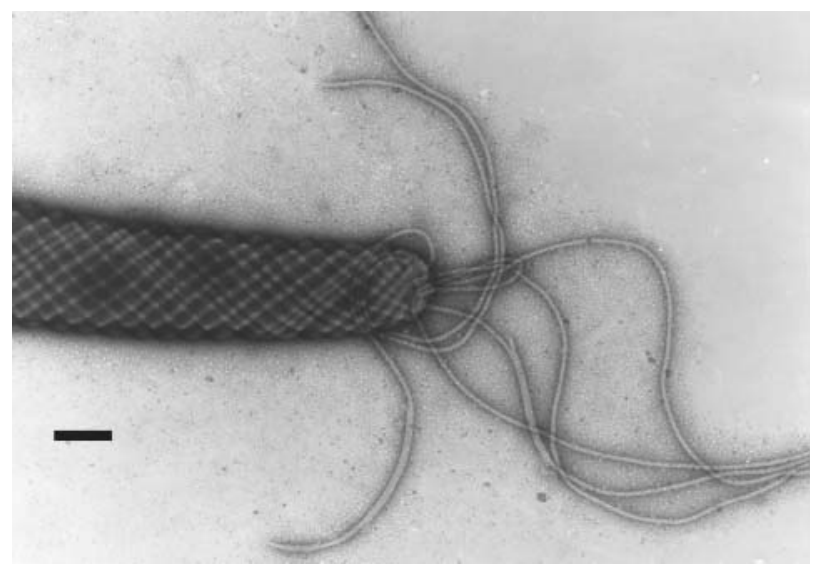

Fig. 8. Helicobacter sp. Higher magnification of fusiform bacterial isolate in Fig. 7, depicting multiple-sheathed flagella. Scale bar $=0.2 \mu \mathrm{m}$ has flexispira morphology (Dewhirst et al. 2000). Most flexispira have been isolated from feces or aborted fetuses, but classic ultrastructural studies by Lockard \& Boler (1970) showed organisms with flexispira morphology in the stomachs of dogs. Helicobacter sp. Flexispira Taxon 7, Strain 1302, was isolated from the stomach of a dog (Dewhirst et al. 2000), and other strains have been isolated from the stomachs of pigs (Hänninen et al. 2003). Thus, helicobacters with flexispira morphology may be found in both gastric and enteric environments. However, to date, all gastric flexispira strains are ureasepositive, whereas some enteric flexispira strains are urease-negative. While the 10 previously described flexispira taxa previously are scattered in the 16S rRNA tree, they cluster into a monophyletic group by 23S rRNA sequencing (J. G. Fox et al. unpubl. obs.).

Helicobacter sp. isolate MIT 01-5529-B was catalaseand oxidase-positive and urease-negative. This isolate clustered closely with $H$. canis (98\% similarity). Interestingly, pinnipeds are believed to share a distant com-

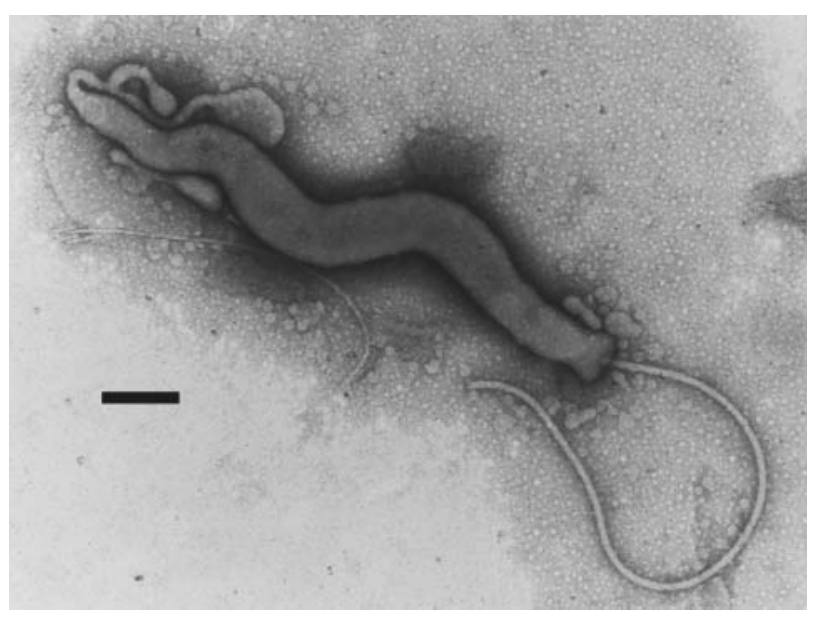

Fig. 9. Helicobacter sp. Transmission electron micrograph of novel curved-to-spiral urease-negative bacterial isolate (MIT 01-5529-B). Note single-sheathed unipolar flagella. Scale bar $=0.2 \mu \mathrm{m}$ 
mon ancestor with dogs; the lineage appears to be most close to the ursid/canid radiation, and otters, seals, sea lions and dogs all cluster in a monophyletic group: Canifornia (within Carnivora) (Lento et al. 1995, Flynn \& Nedbal 1998). H. canis is an enteric pathogen, which is urease- and catalase-negative and oxidasepositive. $H$. canis has been isolated from a colony of Bengal cats with diarrhea, cats without diarrhea, a child with enteritis, a dog with hepatitis, as well as in healthy and diarrheic dogs (Stanley et al. 1993, Fox et al. 1996, Foley et al. 1999, Shen et al. 2001).

Gastric ulcers have been reported in wild and captive pinnipeds. Many of these cases were associated with parasitic infections. However, incidences of nonparasitic gastric ulcers with no clearly defined etiology have also been noted in pinnipeds (Sweeney 1974, 1990).

Histologic sections analyzed from Helicobacter spp.positive harp seals (MIT 01-5529 and MIT 01-5353) displayed 4 of the 5 criteria assessed in the updated Sydney system for grading gastritis including presence of Helicobacter organisms, neutrophil activity, chronic inflammation, and glandular atrophy, while intestinal metaplasia was the only important microscopic feature not seen in the harp seal tissues (Dixon et al. 1994). The chronic active gastritis was accompanied by lymphoid follicle development, and surface epithelial cell degeneration, as documented in humans and other species infected with gastric Helicobacter spp. (Fox 2002). The Warthin-Starry stain clearly showed fusiform to spiral bacteria in the surface mucous layer closely associated with gastric epithelia. Similar findings have been described in other helicobacter-infected species such as Syrian hamsters colonized with $H$. aurati. Interestingly, $H$. aurati is a urease-positive organism that colonizes the gastric antrum and cecum of hamsters, and phylogenetically it clusters with $H$. muridarum as does one of the seal helicobacters (Patterson et al. 2000a,b).

In addition to the Helicobacter spp. infection, the antral glands of Seal MIT 01-5529 were lined by numerous surface-associated, basophilic, 3 to $5 \mu \mathrm{m}$ diameter round organisms with indistinct internal structure, consistent with Cryptosporidium spp. Although concurrent colonization of Helicobacter spp. and Cryptosporidia spp. has been reported in nonhuman primates, no clear correlation was found between the bacterial burden of Helicobacter spp. and the number of protozoa (Dubey et al. 2002). Cryptosporidium spp. infection in pinnipeds was first described by Deng et al. in 2000. They detected $C$. parvum and $C$. duodenalis by PCR in fecal samples from California sea lions Zalophus californianus. Although we could not determine the relative importance of each organism in the seal co-infected with Cryptosporidium spp. and Helicobacter spp. in the development of gastritis, the lesions appeared more consistent with the latter than the former. In other species, Cryptosporidium spp. infection of the stomach can result in a marked proliferative gastropathy with minimal inflammation, features lacking in the stomach of this seal (Massimilo et al. 1995, Kimbell et al. 1999).

Our current findings plus our previously published findings in dolphins and whales suggest that marine mammals may be infected by Helicobacter spp. different from those described for land mammals, and that such infections may be relatively common. Based on what is known about gastric helicobacter infection in other species, it seems reasonable to presume that the novel pinniped Helicobacter spp. may play a role in the etiopathogenesis of gastritis in seals. To our knowledge, this study represents the first isolation and characterization of a Helicobacter spp. from pinnipeds. It might be prudent to include Helicobacter spp. infection in the list of differential diagnoses for seals with clinical signs referable to the gastrointestinal system. Further studies are needed to clarify the role of Helicobacter spp. in the stomach of seals and the role of these bacteria in the etiopathogenesis of gastric diseases in pinnipeds.

Acknowledgements. This work was supported in part by R01AI37750 (J.G.F.) and T32-RR07036 (J.G.F.) and R01-DE10374 (F.E.D.). We thank B. Rubenstein from the New England Aquarium for her collaboration, which enabled us to discover the 2 novel Helicobacter spp. in harp seals.

\section{LITERATURE CITED}

Bishop L (1979) Parasite-related lesions in a bearded seal, Erignathus barbatus. J Wildl Dis 15:285-293

Deng MQ, Peterson RP, Cliver DO (2000) First findings of Cryptosporidium and Giardia in California sea lions (Zalophus californianus). J Parasitol 86:490-494

Dewhirst F, Chien C, Paster B, Paster R, Orcutt R, Schauer D, Fox JG (1999) Phylogeny of the defined murine microbiota: altered Schaedler flora. Appl Environ Microbiol 65: 3287-3292

Dewhirst FE, Fox JG, Mendes EN, Paster BJ, Gates CE, Kirkbride CA, Eaton KA (2000) 'Flexispira rappini' strains represent at least 10 Helicobacter taxa. Int J Syst Evol Microbiol 5:1781-7178

Dixon MF, Genta RM, Yardley JH, Correa P (1994) Classification and grading of gastritis. The updated Sydney system. International Workshop on the Histopathology of Gastritis, Houston. Am J Surg Pathol 20:1161-1181

Doster A (2000) Porcine gastric ulcer. Vet Clin N Am Food Anim Pract 16:163-174

Dubey JP, Markovits JE, Killary KA (2002) Cryptosporidium muris-like infection in stomach of cynomolgus monkeys (Macaca fascicularis). Vet Pathol 39:363-371

Flynn JJ, Nedbal MA (1998) Phylogeny of the carnivora (Mammalia): congruence vs incompatibility among multiple data sets. Mol Phylogenet Evol 9:414-426

Foley J, Marks S, Munson L, Melli A, Dewhirst F, Xu S, Shen Z, Fox J (1999) Isolation of Helicobacter canis from a colony of bengal cats with endemic diarrhea. J Clin Microbiol 37:3271-3275 
Fox JG (1997) The expanding genus of Helicobacter: pathogenic and zoonotic potential. Semin Gastrointest Dis 8: $124-141$

Fox JG (2002) The non- $H$. pylori helicobacters: their expanding role in gastrointestinal and systemic diseases. Gut 50: 273-283

Fox JG, Drolet R, Higgins R, Messier S, Yan L, Coleman B, Paster B, Dewhirst F (1996) Helicobacter canis isolated from a dog liver with multifocal necrotizing hepatitis. J Clin Microbiol 34:2479-2482

Fox JG, Dewhirst F, Shen Z, Feng Y and 7 others (1998) Hepatic Helicobacter species identified in bile and gallbladder tissue from Chileans with chronic cholecystitis. Gastroenterology 114:755-763

Hänninen M, Utriainen M, Happonen I, Dewhirst FE (2003) Helicobacter sp. flexispira 16S rDNA taxa 1, 4 and 5 and Finnish porcine Helicobacter isolates are members of the species Helicobacter trogontum (taxon 6). Int J Syst Evol Microbiol 53:125-433

Harper C, Dangler C, Xu S, Feng Y and 6 others (2000) Isolation and characterization of Helicobacter sp. from the gastric mucosa of dolphins, Lagenorhynchus acutus and Delphinus delphis. Appl Environ Microbiol 66:4751-4757

Harper C, Xu S, Feng Y, Dunn J, Taylor N, Dewhirst F, Paster B, Fox JG (2002a) Isolation of novel Helicobacter spp. from a beluga whale. Appl Environ Microbiol 68:2040-2043

Harper C, Feng Y, Xu S, Taylor N and 7 others (2002b) Helicobacter cetorum sp. nov., a urease-positive Helicobacter species isolated from dolphins and whales. J Clin Microbiol 40:4536-4543

Kimbell LM III, Miller DL, Chavez W, Altman N (1999) Molecular analysis of the 18S rRNA gene of Cryptosporidium serpentis in a wild-caught corn snake (Elaphe guttata guttata) and a five-species restriction fragment length polymorphism-based assay that can additionally discern C. parvum from C. wrairi. Appl Environ Microbiol 65:5345-5349

Lento GM, Hickson RE, Chambers GK, Penny D (1995) Use of spectral analysis to test hypotheses on the origin of pinnipeds. Mol Biol Evol 12:28-52

Lockard V, Boler RK (1970) Ultrastructure of a spiraled microorganism in the gastric mucosa of dogs. Am J Vet Res 31:1453-1462

Editorial responsibility: Murray Dailey,

Sausalito, California, USA
Massimillo AJ, Chang J, Freedman L, Baxi R, Kanth N, Pellecchia C (1995) Cryptosporidium gastropathy. Presentation of a case and review of the literature. Dig Dis Sci 40: 186-190

McClelland G (1980) Phocanema decipiens: pathology in seals. Exp Parasitol 49:405-419

Mendes E, Quieroz, Dewhirst F, Paster B, Moura S, Fox J (1996) Helicobacter trogontum sp. nov., isolated from the rat intestine. Int J Syst Bacteriol 46:916-921

Patterson M, Schrenzel M, Feng Y, Fox JG (2000a) Gastritis and intestinal metaplasia in Syrian hamsters infected with Helicobacter aurati and two other microaerobes. Vet Pathol 37:589-596

Patterson MM, Schrenzel MD, Feng Y, Xu S and 5 others (2000b) Helicobacter aurati sp. nov., a urease-positive Helicobacter species cultured from gastrointestinal tissues of Syrian hamsters. J Clin Microbiol 38:3722-3728

Riedman M (1990) The pinnipeds seals, sea lions, and walruses. University of California Press, London

Saitou N, Nei M (1987) The neighbor-joining method: a new method for reconstructing phylogenetic trees. Mol Biol Evol 4:406-425

Shen Z, Feng Y, Dewhirst F, Fox JG (2001) Coinfection of enteric Helicobacter spp. and Campylobacter spp. in cats. J Clin Microbiol 39:2166-2172

Stanley J, Linton D, Burnens D, Dewhirst F, Owen R, Porter A, On R, Costas M (1993) Helicobacter canis sp. nov., a new species from dogs: an integrated study of phenotype and genotype. J Gen Microbiol 139:2495-2504

Sweeney J (1974) Common diseases of pinnipeds. J Am Vet Med Assoc 165:805

Sweeney J (1990) Marine mammal behavioral diagnostics. In: Dierauf L (ed) CRC handbook of marine mammal medicine: health, disease, and rehabilitation, 1st edn. CRC Press, Boca Raton, FL, p 57

Versalovic J, Fox JG (2001) Taxonomy and phylogeny of Helicobacter. In: Achtman M, Suerbaum S (eds) Helicobacter pylori: molecular and cellular biology. Horizon Scientific Press, Wymondham, UK, p 15-28

Versalovic J, Fox JG (2003) Helicobacter. In: Murray PR et al. (eds) Manual for clinical microbiology, 8th edn. ASM Press, Washington, DC, p 915-928

Submitted: May 7, 2003; Accepted: July 3, 2003

Proofs received from author(s): September 18, 2003 